\title{
Chapter 1 \\ What Does It Mean to Be a Nonprofit \\ Educational Measurement Organization in the Twenty-First Century?
}

\author{
Randy E. Bennett
}

The philosopher George Santayana (1905) said, "Those who cannot remember the past are condemned to repeat it" (p. 284). This quote is often called, "Santayana's Warning," because it is taken to mean that an understanding of history helps avoid having to relive previous mistakes. But the quote can also be read to suggest that, in order to make reasoned decisions about the future, we need to be always cognizant of where we have come from. This claim is especially true for a nonprofit organization because its continued existence is usually rooted in its founding purposes.

This chapter uses Educational Testing Service (ETS), the largest of the nonprofit educational measurement organizations, to illustrate that claim. The chapter is divided into four sections. First, the tax code governing the establishment and operation of educational nonprofits is reviewed. Second, the history around the founding of ETS is described. Third, the implications of ETS's past for its future are discussed. Finally, the main points of the paper are summarized.

\footnotetext{
This chapter was originally published in 2005 by Educational Testing Service.

R.E. Bennett $(\varangle)$

Educational Testing Service, Princeton, NJ, USA

e-mail: rbennett@ets.org
} 


\subsection{What Is an Educational Nonprofit?}

The term nonprofit refers to how an organization is incorporated under state law. To be federally tax exempt, an educational nonprofit must become a 501(c)3 corporation. ${ }^{1,2}$ What is 501(c)3? It is a very important section in the Internal Revenue Code. The section is important because of what it does, and does not, allow educational nonprofits to do, as well as because of how the section came about.

Section 501(c)3 exempts certain types of organizations from federal income tax. ${ }^{3}$ To qualify, an organization must meet certain discrete "tests." The tests are the organizational test, operational test, inurement test, lobbying restriction, electioneering prohibition, public benefit test, and public policy test (Harris 2004). Each of these tests is briefly reviewed in turn.

Under the Internal Revenue Code, to be exempt, an organization must be set up exclusively for one or more of the following purposes: charitable, religious, educational, scientific, literary, testing for public safety, fostering amateur national or international sports competition, or the prevention of cruelty to children or animals (Internal Revenue Service [IRS] 2003b). An entity meets this organizational test if its articles of incorporation limit its function to one or more exempt purposes (e.g., educational) and do not expressly allow the organization to engage, other than insubstantially, in activities that are not consistent with those purposes.

ETS's exempt purpose is educational and its organizing documents specify the activities it can pursue in keeping with that purpose. Paraphrasing the 2005 revision of the organization's charter and bylaws (ETS 2005), those activities are to:

- Conduct educational testing services,

- Counsel test users on measurement,

- Serve as a clearinghouse about research in testing,

- Determine the need for, encourage, and carry on research in major areas of assessment,

- Promote understanding of scientific educational measurement and the maintenance of the highest standards in testing,

- Provide teachers, parents, and students (including adults) with products and services to improve learning and decisions about opportunities,

- Enhance educational opportunities for minority and educationally disadvantaged students, and

- Engage in other advisory services and activities in testing and measurement from time to time.

\footnotetext{
${ }^{1}$ For purposes of this chapter, nonprofit and 501(c) 3 corporation are used to mean the same thing, even though they are legally different.

${ }^{2}$ The terms nonprofit and not-for-profit are not legally distinct, at least not in the Internal Revenue Code.

${ }^{3}$ The IRS has 27 types of organizations that are tax exempt under 501(c), only one of which covers those institutions exempt under 501(c)3 (Internal Revenue Service [IRS] 2003a).
} 
To meet the second-or operational—test, the organization must be run exclusively for one or more of the exempt purposes designated in its articles. The test is met if the organization's stated purpose and activities conform. Although Section 501(c)3 indicates that the organization must be operated "exclusively" for exempt purposes, the term exclusively has been interpreted by the IRS to mean "primarily" or "substantially." Thus, Section 501(c)3 does allow exempt organizations to engage in activities unrelated to their exempt purposes (IRS 2000). But those activities must not become "substantial" and tax must be paid on this unrelated business income.

Note that the operational test makes clear that engaging in unrelated activities to support the exempt purpose is, in itself, a nonexempt purpose, if it is done any more than insubstantially (IRS n.d.-a). ${ }^{4}$ To prevent such unrelated activities from becoming so substantial that they threaten tax-exempt status-as well as to allow outside investment and limit liability_an exempt organization may create for-profit subsidiaries. $^{5}$

The inurement test is often cited as the fundamental difference between for-profit and nonprofit corporations. This test says that no part of the organization's net earnings may benefit any private individual. For example, there may be no stockholders and no distribution of net earnings, as in a dividend.

The lobbying restriction and electioneering prohibition mean, respectively, that no significant part of an organization's activities may consist of "carrying on propaganda or otherwise attempting to influence legislation..." and that an exempt organization may not participate or intervene in any political campaign for or against any candidate for public office (IRS n.d.-b). ${ }^{6}$ Unlike the lobbying restriction, the electioneering prohibition is absolute.

To meet the public benefit test, the organization must operate for the advantage of public, rather than private, interests. ${ }^{7}$ Private interests can be benefited, but only incidentally. Further, the principal beneficiaries of the organization's activities must be sufficiently numerous and well-defined, so that the community is, in some way, served.

Finally, there is the public policy test, which essentially says that an otherwise qualifying organization's "... purpose must not be so at odds with the common community conscience as to undermine any public benefit that might otherwise be conferred" (Bob Jones University v. United States 1983). The quintessential example is Bob Jones University, which lost its tax-exempt status as a result of racially

\footnotetext{
${ }^{4}$ There does not appear to be a statutory or regulatory definition of substantial. However, experts in nonprofit tax law often advise limiting gross unrelated business income to under $20 \%$ of gross revenue (e.g., FAQ's—501(c)(3) Status (n.d).

${ }^{5}$ The Chauncey Group International would be one example from ETS's history.

${ }^{6}$ The dollar limits associated with the lobbying restriction are defined by a relatively complex formula. See Restrictions on Nonprofit Activities (n.d.). Also see IRS (n.d.-c).

${ }^{7}$ This test differs from the inurement test in that the inurement test applies only to insiders-persons having a private interest in the organization's activities—-whereas the "private interests" cited in the public benefit test apply more generally.
} 
discriminatory practices that the IRS believed, and the Supreme Court affirmed, violated fundamental public policy. ${ }^{8}$

Organizations set up for educational purposes under 501(c)3 have several additional requirements (IRS 2003b). First, the "positions" they take must be educational. According to the IRS, "Advocacy of a particular position ... may be educational if there is a sufficiently full and fair exposition of pertinent facts to permit an individual or the public to form an independent opinion or conclusion" (IRS 2003b, p. 25). Also, the method used by an organization to develop and present its views is a factor in determining if the organization is "educational."

What constitutes an "educational" method? The IRS says that the method is not educational when:

1. The presentation of viewpoints unsupported by facts is a significant part of the organization's communications.

2. The facts that purport to support the viewpoints are distorted.

3. The organization's presentations express conclusions more on the basis of emotion than objective evaluation. (IRS 2003b, p. 25)

That, then, is what 501(c)3 is about. But why did Congress decide to grant tax exemptions to certain organizations in the first place, thereby forgoing huge amounts of future revenue?

The statutory roots of 501(c)3 are commonly traced to the Tariff Act of 1894, which imposed a corporate income tax and exempted entities organized and conducted solely for charitable, religious, or educational purposes from having to pay it (Scrivner 2001). The congressional intent behind the exemption was to give preferential treatment because such organizations provided a benefit to society. Congress reaffirmed this view in the Revenue Act of 1938 when it said that tax exemption was based on the theory that the loss of revenue is compensated by relieving the government of a function it would otherwise have to perform (presumably because the for-profit sector would not, or should not be allowed to, perform it) and because of the benefits to the general welfare that the function would serve (Bob Jones University v. United States 1983). ${ }^{9}$

The Revenue Act of 1950 added unrelated business income tax rules, which were intended to eliminate unfair competition by taxing the unrelated activities of exempt

\footnotetext{
${ }^{8}$ The IRS revoked the tax-exempt status of Bob Jones University in 1975 even though the school had not violated any provision of 501(c)(3). The IRS revoked its tax-exempt status because the university had, on the basis of religious belief, at first, refused admission to Black students, and then only to Black students married within their own race. It then admitted Black students generally but enforced strict rules, including expulsion, against interracial dating. The university sued when its exempt status was revoked. The Supreme Court upheld the IRS decision by an 8-1 vote. ${ }^{9}$ Why shouldn't the for-profit sector supply some services? Because the need for profit may come into direct conflict with the intended public benefit behind the service. Some services require a disinterested party. See, for example, the inurement test, the lobbying restriction, and the electioneering prohibition, which are intended to distance the service provider from self-interest that could otherwise affect the provision of the service. Occupational and professional licensing and certification, which is often handled by private nonprofit associations, would be an example.
} 
organizations in the same way as competing for-profit corporations were taxed (Scrivner 2001). The Internal Revenue Code of 1954 was a restructuring to the current numbering, which resulted in the section known today as "Section 501(c)3." Finally, the 1959 Regulations for the 1950 Act and the 1954 Code defined charity to more closely approach the English common-law definition (Scrivner 2001). That is, not only the relief of poverty, but also the advancement of education, religion, and other purposes beneficial to the community. So, legally, many 501(c)3 organizations like ETS are, in fact, "public charities." 10

To summarize, in the words of the majority opinion rendered by the U.S. Supreme Court in Bob Jones University v. United States (1983), "In enacting ... 501(c)3, Congress sought to provide tax benefits to charitable organizations to encourage the development of private institutions that serve a useful public purpose or supplement or take the place of public institutions of the same kind."

Thus, Section 501(c) 3 has its roots in the idea that the government might not be able to provide all the services the public needs, that the for-profit sector might not fill the gap, and that those organizations that do voluntarily address such social needs should be compensated through tax exemption.

How did ETS come to be a 501(c)3? The reasons for that lie fundamentally in how ETS came about. That story begins at the end of the nineteenth century, just prior to the establishment of the College Entrance Examination Board.

\subsection{Where Did ETS Come From?}

Prior to the founding of the College Entrance Examination Board (CEEB), admission to college and university in the United States was a disorganized, if not chaotic process (Fuess 1950). The Ivy League institutions each administered their own tests, which varied widely in subjects assessed, quality, and administration date. Wilson Farrand, principal of Newark Academy, summarized the disarray in entrance requirements as follows (cited in Fuess 1950, p. 17):

\footnotetext{
Princeton requires Latin of candidates for one course, but not for the others. Yale demands it of all, Columbia of none. Princeton names five books of Caesar and four orations of Cicero; Yale names four books of Caesar and three books of Virgil ... Yale calls for Botany, Columbia for Physics and Chemistry, Princeton for no science. Princeton and Columbia demand both German and French, while Yale is satisfied with either. On the other hand, while Princeton and Columbia demand only American History, Yale calls also for that of England...
}

Other colleges annually reviewed and certified high schools so that they had a means of assuring the quality of the curriculum and of the recommendations coming from school principals (Fuess 1950; Hubin 1988). This certification system was

\footnotetext{
${ }^{10}$ All 501(c)3 organizations must be categorized under Section 509(a) as either private foundations or one of several types of public charity. See IRS (2003b, pp. 30-36) for the particulars of this classification.
} 
a burden for both the colleges and the high schools. College staff had to physically visit each feeder school and each feeder school had to undergo multiple reviews annually, one for each receiving college.

To help rationalize admissions, the CEEB was established in 1900 through the Association of Colleges and Secondary Schools of the Middle States and Maryland, with 12 collegiate charter members, as well as representation from three secondary schools (Fuess 1950). ${ }^{11}$ The Board's initial purpose was to create a single battery of centrally scored examinations and, in so doing, bring order and higher quality to the college preparatory curriculum. The first "College Boards," as they were called, were administered the following year, 1901.

The College Boards were a weeklong battery of essay tests in various content domains, which solved some problems but brought others to the fore (Hubin 1988). By the early 1920s, the CEEB membership, which now included secondary schools, was unhappy enough with the exams that it began publicly voicing concerns about their subjectivity in scoring, variation in difficulty from one administration (or form) to the next, and the narrowing effect the exams were having on the high school curriculum. ${ }^{12}$

As a consequence of its unhappiness, the Board commissioned two streams of investigation, with the idea being to supplement, not replace, the essay tests (Hubin 1988). The first stream of investigation focused on multiple-choice achievement tests and was led by Edward L. Thorndike and Ben D. Wood of Teachers College, Columbia University.

The second stream centered on multiple-choice intelligence tests derived from Yerkes' 1918 Army Alpha Test. The Board referred to this project as its "Psychological" examinations, and it was led by Carl Brigham of Princeton University.

As the Board was pursuing its twin investigations, the American Council on Education (ACE), began its own initiative to develop "psychological examinations." ACE was founded in 1918, as an association dominated by public universities. (The much smaller CEEB, in contrast, was composed primarily of private institutions.) In 1924, ACE commissioned Louis. L. Thurstone, of the Carnegie Institute of Technology, to create an admissions test based on Army Alpha. ${ }^{13}$ ACE took this course of action because many public institutions were already using intelligence tests in admissions and ACE wanted to standardize this use (Hubin 1988).

Meanwhile, under the auspices of the CEEB, Brigham had by 1926 developed his "psychological" examination but under a new name because, Brigham, originally a eugenicist, no longer believed that intelligence tests measured native ability.

\footnotetext{
${ }^{11}$ The charter members were: Barnard College, Bryn Mawr College, Columbia University, Cornell University, Johns Hopkins University, New York University, Rutgers College, Swarthmore College, Union College, University of Pennsylvania, Vassar College, and the Woman's College of Baltimore (Fuess 1950).

${ }^{12}$ These issues, incidentally, remain with us in one way or another to this day.

${ }^{13}$ The Carnegie Institute would later merge with the Mellon Institute of Industrial Research to form Carnegie-Mellon University.
} 
And in the first SAT ${ }^{\circledR}$ manual (Brigham 1926, cited in Hubin 1988, pp. 196-197), he was quite clear:

The term 'scholastic aptitude' makes no stronger claim ... than that there is a tendency for ... scores in these tests to be associated positively with ... subsequent academic attainment.

Further:

This additional test ... should be regarded merely as a supplementary record.

To evaluate Brigham's predictive validity claim, the CEEB began to administer the test experimentally that same year (Hubin 1988).

The story next moves to Harvard. The year was 1933 and the country was in the midst of its Great Depression. James Bryant Conant had just become president. As president, Conant found that applicants were being drawn primarily from a small number of northeastern preparatory schools and that the "College Boards" were still being used for admission (Hubin 1988). Conant disliked the "College Boards" because he saw them as nothing more than a measure of mastery of the prep school curriculum that couldn't be used to assess students coming from public schools. For Conant, Harvard admission was being based largely on ability to pay because if a student could not afford to attend prep school, that student was not going to do well on the College Boards and was not coming to Harvard.

Conant decided to address this problem by creating a scholarship program to increase economic and regional diversity (Hubin 1988). Note that Conant did not want to increase access to Harvard for everyone, but just for those with academic talent. How would one measure academic talent in the public schools? Obviously not with the College Boards, which were keyed toward the prep school curriculum. To find a solution, Conant turned to Henry Chauncey, his assistant dean of admissions. Chauncey contacted Carl Brigham, who was by this time associate director for research at the CEEB, on leave from Princeton University.

Chauncey arranged with the CEEB for Brigham's Scholastic Aptitude Test to be used for the award of Harvard scholarships in the very next year (1934), and by 1937, the "Scholarship Tests," as they were now being called, were used by 14 colleges. The Scholarship Tests were composed of two parts: the Scholastic Aptitude Test, as developed by Brigham, and a battery of achievement tests created by Ben Wood for ACE's Cooperative Test Service. This use of the Scholarship Tests was funded by the Carnegie Foundation for the Advancement of Teaching. In the following year, 1938, the Scholarship Tests were extended to use for university admissions.

Within the Scholarship Test project were collaborating the three organizations that would later form ETS: the College Entrance Examination Board, the American Council on Education, and the Carnegie Foundation for the Advancement of Teaching. This third organization, the Carnegie Foundation, was established by Andrew Carnegie in 1905 as an independent policy and research center to "... encourage, uphold, and dignify the profession of the teacher and the cause of higher education" (Carnegie Foundation for the Advancement of Teaching 2005). Around 
the time the Scholarship Tests were being put into place, William Learned of the Foundation was also encouraging development of the GRE® assessment as an experimental test for admissions to graduate liberal arts programs (Hubin 1988). The GRE consisted of an aptitude test, which was the SAT, and a battery of achievement tests created by Wood for ACE. The GRE was first administered experimentally at Harvard, Yale, Princeton, and Columbia in 1937, the very same year the Scholarship Tests were extended beyond Harvard.

Just as the GRE and the Scholarship Tests were being introduced, several key figures floated the idea of a unified testing organization (ETS 1992). In a 1937 speech at the annual meeting of the Educational Records Bureau, Conant advocated for formation of a "nationwide cooperative testing service" because he believed that standardized testing would be advanced by a substantial research program concentrated in one organization. Around the same time, Learned of Carnegie approached Wood of ACE about forming a "general examinations board" because Learned believed that testing could be made more efficient by eliminating competition and duplication, and because Learned thought that more resources would be available for research and development if a unified organization was formed (Hubin 1988).

George Mullins, CEEB Secretary, described the philosophical foundation that such an organization should have (ETS 1992, p. 9). He wrote:

The organization should be built so that it can attack the problems of educational measurement scientifically ... It should have no doctrine to sell, no propaganda concerning certain forms of tests to be spread ... It must be an open-minded scientific organization if it is destined to give real service and therefore to endure.

So, clearly, scientific research was a principal motivation for the advocates of a unified testing organization. And, paradoxically, scientific research was also a motivation for those opposed. The strongest opponent was Carl Brigham (ETS 1992; Hubin 1988; Lemann 1999). What were Brigham's concerns?

First, Brigham did not believe that psychology or measurement was scientifically advanced enough to support the large-scale operational use of testing that a national agency would bring. He wrote (cited in Lemann 1999, p. 34):

Practice has always outrun theory...this is a new field and...very little has been done which is right.

What was not right? A prime example comes from an earlier letter (cited in Lemann 1999, p. 33):

The more I work in this field, the more I am convinced that psychologists have sinned greatly in sliding easily from the name of the test to the functions or trait measured.

This comment referred to the ease with which the psychologists of the day had concluded that IQ tests measured innate intelligence tied to ethnicity, a view he himself had taken but since, quite publicly, rejected (Hubin 1988).

A second reason for Brigham's opposition to a unified measurement organization was that he believed consolidation would slow the growth of measurement science and kill innovation in tests. In a letter to Conant (cited in ETS 1992, p. 6), he wrote: 
One of my complaints against the proposed organization is that although the word research will be mentioned many times in its charter, the very creation of powerful machinery to do more widely those things that are now being done badly will stifle research, discourage new developments, and establish existing methods, and even existing tests, as the correct ones.

What kind of innovation did Brigham wish to see? Among other things, Brigham was interested in connecting tests to teaching, learning, and cognition (Donlon 1979; Hubin 1988). Ideas in his 1932 book, A Study of Error, anticipated by a halfcentury what we, today, call formative assessment. Brigham believed that the mistakes students made in solving test items could provide a basis for instruction.

But according to Lemann (1999), what concerned Brigham most was that any organization that owned the rights to a particular examination would inescapably become more interested in marketing that test than in objectively researching its effectiveness and working toward its improvement. For Brigham, a strong research program, not just lip service, was essential because "The provision for extensive research will prevent degeneration into a sales and propaganda group..." (Brigham 1937, p. 756). Brigham's opposition was so strident, and his opinion so respected, that the idea for a consolidated organization was shelved-that is, until Brigham died in January of 1943 at the relatively young age 52 .

Coincidentally, by the time Brigham died, the need for a unified testing agency had become more pronounced. In the 1940s, the CEEB was still primarily a regional membership organization, though it had grown from its original 12 institutions to more than 50 (Fuess 1950). While membership growth was certainly desirable, the Board found it difficult to integrate the increased operational testing activity it had to perform. The SAT was now equated and machine scored, making it both fairer and far more efficient to process than the College Boards. In 1941, the old College Boards were discontinued, which from William Learned's point of view, could have been no great loss, for he had earlier described them as "a few arbitrarily chosen questions with answers rated in terms of personal opinion by individuals of varying degrees of experience and competence" (cited in Hubin 1988, pg. 293).

The 1940s saw the CEEB's operational testing activities balloon. Initially, this growth came from large military contracts during the Second World War, most of which had nothing to do with educational testing and which, consequently, made the Board's membership of admissions officers quite uneasy (Hubin 1988). This activity was followed by an upsurge in college applicants after the war because of the GI Bill, which paid essentially the full cost of college for returning veterans.

Meanwhile, the Carnegie Foundation had its own concerns. In 1944, the GRE had gone operational and by 1946, the GRE unit had more staff than the Foundation proper (Hubin 1988). While the Foundation had hoped for such success, it was in the business of seeding development, not running established testing programs so, like the Board, it too was looking for a home for its "Big Test."

Finally, ACE's Cooperative Test Service (CTS) was operating at a loss (Lemann 1999). Moreover, ACE, which saw the CEEB as a competitor, did not want the CEEB to get the GRE. Thus, all three organizations had their own motivations for wanting a centralized testing agency. Carnegie took the next step by sponsoring a national commission, chaired by Conant, to recommend how to proceed. 
When the Commission issued its recommendations, there was considerable negotiation, much of it facilitated by Henry Chauncey, over whether the agency should be a functionary of one of the three organizations or independent of them (ETS 1992; Lemann 1999). Finally, the three organizations agreed on an independent arrangement in which they would turn over their testing programs and a portion of their assets to the new ETS (ETS, 1992; Fuess 1950). Among other things, the CEEB contributed SAT operations, Law School Admission Test (LSAT) operations, 139 permanent employees, and its Princeton office. Carnegie gave the GRE, the Pre-Engineering Inventory, and 36 employees. ACE donated the Cooperative Test Service, which included NTE operations (and later full ownership), Thurstone's Psychological Examination, and 37 employees. ${ }^{14}$

In December 1947, ETS was granted a charter by the New York State Board of Regents. James Conant was designated chairman of the Board of Trustees. Henry Chauncey, now a director of the CEEB, was named ETS's first president, in recognition of the role he played in bringing the three organizations together.

Interestingly, neither the Board of Trustees, nor Henry Chauncey, forgot Carl Brigham's warnings about the need for research as a mechanism for driving innovation, helping maintain high standards, and, ultimately, for improving education. With respect to improving education, after its first meeting, the ETS Board of Trustees issued the following statement (cited in ETS 1992, p. 22):
In view of the great need for research in all areas and the long-range importance of this work to the future development of sound educational programs, it is the hope of those who have brought the ETS into being that [through its research] it make fundamental contribu- tions to the progress of education in the United States.

Henry Chauncey also made the connection between research and improvements to education. In his inaugural message to staff (cited in ETS 1992, pp. 21-22), he wrote:

It is our ardent hope and confident expectation that the new organization will make important contributions to American education through developing and making available tests of the highest standards, by sponsoring distinguished research both on existing tests and on unexplored test areas, and by providing effective advisory services ... to schools and colleges.

For Henry Chauncey, these were not just words. Over his tenure as ETS president, traditions for the conduct of research were established to forestall precisely the problems that Brigham feared. Chauncey put into place academic freedom to encourage independent thinking and constructive criticism of ETS's own tests, thereby fostering opportunities for the instruments' improvement. He put into place a policy requiring full publication of research results, unless the outcomes of a project were identified in advance as proprietary and confidential. He established this policy for two reasons. The first reason was to prevent the suppression of results unfavorable to ETS or its testing programs because, if suppression occurred, it would signal the organization's descent into producing "propaganda" to serve its

\footnotetext{
${ }^{14}$ Each organization also contributed capital in the form of cash or securities (Fuess 1950).
} 
own ends. ${ }^{15}$ A second reason for the publication policy was that Chauncey saw advancing the fields of education and measurement as a corporate obligation, and publication as a mechanism for achieving it.

Henry Chauncey also put into place a funding source that was purposely not controlled by the testing programs. He did this to encourage long-term, forward thinking projects unconstrained by short-term business needs. Last, he actively encouraged a wide-ranging agenda to push innovation along many measurement and education fronts simultaneously. Collectively, Chauncey's traditions had one other important effect. They created an environment that allowed him to attractand retain — the brightest young research staff_LLord, Messick, Tucker, Gulliksen, Frederiksen - and, as a result, build ETS's reputation as a scientific educational measurement organization.

To summarize, Conant, Chauncey, Learned, and the others who spearheaded the creation of ETS saw the new organization as providing a public service that neither the government nor the private sector offered. In this way, the public service principles underlying the founding of ETS and those of the Internal Revenue Code met, with ETS being established as a nonprofit corporation.

Turning back to Santayana, "How might an organization like ETS use its past, in particular its public service roots, to help shape its future?" In other words, "How can such an organization succeed as a nonprofit educational measurement organization in the twenty-first century?"

\subsection{What Does the Past Imply for the Future?}

To answer these questions requires a close look at the idea of mission. Section 501(c)3 doesn't use that word. It uses the term purpose to describe the reason for which an exempt organization is operated. What's an organizational mission? It is, essentially, nothing more than a statement of purpose. Logically then, a nonprofit organization's mission must be aligned with its exempt purpose, otherwise, the organization could not remain exempt. ETS's mission is “... to help advance quality and equity in education by providing fair and valid assessments, research and related services," which is quite close in meaning to the inaugural words of the Trustees and of Henry Chauncey, as well as to ETS's chartered purpose. ${ }^{16}$

As noted earlier, the overwhelming majority of activities an exempt organization conducts must be consistent with its purposes under section 501(c)3. Such an

\footnotetext{
${ }^{15}$ It is interesting to note the repeated appearance of the word propaganda in the story of ETS. Brigham feared it, George Mullins (CEEB) hoped a unified organization would transcend it, the IRS enjoined educational nonprofits against it, and Henry Chauncey made sure to do something about it.

${ }^{16}$ ETS's chartered purpose reads as follows (ETS 2005): “The purposes for which the corporation is formed are to engage in, undertake, and carry on services, research and other activities in the field of educational testing and such other activities as may be appropriate to such purpose."
} 
organization may not, as a primary operating strategy, use unrelated business to fund its mission (IRS n.d.-a). So, what additional strategies are available to fund the mission for such an organization?

One strategy often used by educational nonprofits with large endowments is to fund activities through investment proceeds. But this approach is not a long-term operating strategy for an organization like ETS whose relatively limited reserves are needed to drive innovation and cover unforeseen emergencies.

A second mechanism is through for-profit subsidiaries, which protect the exempt status of the parent from unrelated income and allow outside investment. ETS used this approach in the 1990s with the establishment of Chauncey Group International (CGI), K12 Works, and ETS Technologies. CGI was sold in 2004 to Thomson Prometric and the other two subsidiaries were incorporated into ETS proper a short time earlier. More recently ETS has created several new subsidiaries, including one for-profit, ETS Global, B.V.

The third strategy is to fund the mission through the mission-in essence, through new product and service development because, in ETS's case, the products that originally funded the mission - in particular, the SAT and GRE-are no longer providing the income growth needed to support continued innovation.

There is, of course, a catch to funding the mission through mission-related new product and service development. Obviously, these new products and services need to be financially successful. That is not the catch.

The catch is that, to be truly mission oriented, this new product and service development needs to be different in some fundamental way from the products and services that for-profits offer. Otherwise, what justifies nonprofit status? How can it be a public service if the for-profit sector is offering the very same thing?

How, then, does an organization like ETS differentiate itself?

ETS has typically tried to differentiate itself by providing higher levels of quality - or of integrity - than the for-profits offer. And when people's life-chances are at stake, that is a public service.

But there may be something more that it can do. That "something more" is to take on the big challenges the for-profits will not because the challenges are too hard — and they don't have the scientific capability to attack them-or because the return on investment isn't big enough or soon enough — and their need to satisfy shareholders won't allow it.

What are the big challenges? Arguably, the best examples can be found in the work of ETS's progenitors. Carl Brigham was interested in going beyond the SAT's selection function to using assessment to guide instruction. And what better time to pursue that goal than now? The relevant questions today are:

- Who needs help?

- With what specific content standards?

- How should they be taught those specific standards?

These questions are especially important to address in the case of minority and economically disadvantaged students, for whom closing the achievement gap has become a critical national issue. 
For his part, Henry Chauncey had enormous interest in measuring new constructs to guide individuals in educational choices (Lemann 1999). He wanted to know:

- What are individuals good at?

- What are they interested in?

- How can those aptitudes and interests be guided for the good of the individual and society?

Finally, James Conant's original interest was using assessment to increase diversity. In today's terms:

- How can we better locate promising individuals from all backgrounds for purposes of encouraging them to pursue higher education?

- How can we help them further develop the skills they will need to succeed (including such new basics as English for second-language learners)?

The challenges that Brigham, Chauncey, and Conant posed well over 50 years ago remain largely unresolved today. If nonprofit measurement organizations like ETS can create financially successful new products and services that meet those challenges, they will be doing as they should: funding their mission by doing their mission.

But nonprofit organizations like ETS do not have a chance of realizing this goal without reorienting themselves dramatically. For one, they need to be more responsive to market needs. Being responsive means:

- Scientific research and development that solves problems customers care about,

- Business units that influence the choice of problems to be solved and that help shape those solutions into marketable products,

- Sales and marketing functions that effectively communicate what differentiates a nonprofit's products from competitor offerings, and that bring back intelligence about customer needs, product ideas, and potential product improvements,

- Technology delivery that can readily and cost-effectively incorporate advances, and

- Operational processes that execute accurately and efficiently.

However, in addition to being more responsive, such organizations need to be more responsible. Being responsible means:

- Products and marketing claims the organization can stand behind scientifically,

- Research that supports, but is not controlled by, the business units, and

- Research and development investments that are determined not only by financial return but also mission return (i.e., the positive impact on education the product or service is expected to have).

Ultimately, being "responsible" means continuing to champion integrity, quality, and scientific leadership in educational measurement and in education. 


\subsection{Summary}

ETS is a nonprofit educational measurement organization with public service principles deeply rooted in its progenitors and in Section 501(c)3. Both its progenitors and the framers of the tax code were interested in the same thing: providing a social benefit.

A corollary of this history is that the purpose of a nonprofit measurement organization like ETS is not about making money. Its purpose is not even about making money to support its mission (because that, in itself, would be a nonexempt purpose). Its purpose is about doing its mission, making enough money in the process to continue doing it in better and bigger ways.

Third, it is reasonable to argue that, in the twenty-first century, renewed meaning can be brought to ETS's mission by attacking big challenges in education and measurement, such as using assessment to guide instruction, measuring new constructs to help individuals with educational choices, and using assessment to increase diversity. Interestingly, many of these big challenges are the same ones that motivated the organization's progenitors. Those individuals knew these were hard problems but they had faith that those problems could be solved. To solve them, ETS and organizations like it will need to act more responsively and more responsibly than ever before.

Make no mistake: If ETS succeeds in being responsive without being responsible, or in being responsible without being responsive, it will have failed. ETS, and kindred organizations, must do both. Doing both is what it means to be a nonprofit educational measurement organization in the twenty-first century.

Acknowledgments I am grateful to the following people for providing information, comments, or other assistance to me in developing the presentation on which this chapter was based: Isaac Bejar, Michal Beller, Julie Duminiak, Marisa Farnum, Eleanor Horne, Pat Kyllonen, Ernie Price, Larry Stricker, Rich Swartz, Stan Von Mayrhauser, Dylan Wiliam, and Ann Willard. However, all opinions contained herein, and any errors of fact, are my own.

\section{References}

Bob Jones University v. United States, 461 U.S. 574 (1983).

Brigham, C. C. (1937). The place of research in a testing organization. School and Society, 46, 756-759.

Carnegie Foundation for the Advancement of Teaching. (2005). About the Carnegie Foundation. Retrieved from http://web.archive.org/web/20041211123245/http://www.carnegiefoundation. org/AboutUs/index.htm

Donlon, T. F. (1979). Brigham's book. The College Board Review, 113, 24-30.

Educational Testing Service. (1992). The origins of Educational Testing Service. Princeton: Author.

Educational Testing Service. (2005). Educational Testing Service: Charter and bylaws (revised April 2005). Princeton: Author.

FAQ's-501(c)(3) status. (n.d.). Retrieved from http://web.archive.org/web/20050113093311/ http://www.t-tlaw.com/lr-04.htm 
Fuess, C. M. (1950). The College Board: Its first fifty years. New York: Columbia University Press. Harris, J. A. (2004). Requirements for federal income tax exemption under code section 501(c)3. Retrieved from http://web.archive.org/web/20040107112241/http://www.zsrlaw.com/publications/articles/jah1999.htm

Hubin, D. R. (1988). The Scholastic Aptitude Test: Its development and introduction, 1900-1947. Retrieved from http://darkwing.uoregon.edu/ hubin/

Internal Revenue Service. (2000). Tax on unrelated business income of exempt organizations (IRS publication 598). Retrieved from http://web.archive.org/web/20030316230904/http://www.irs. gov/pub/irs-pdf/p598.pdf

Internal Revenue Service. (2003a). IRS data book 1998-2001 Retrieved from http://web.archive. org/web/20050519035227/http://www.irs.gov/pub/irs-soi/01db22eo.xls

Internal Revenue Service. (2003b). Tax exempt status for your organization (IRS publication no. 557). Retrieved from http://web.archive.org/web/20040102203939/http://www.irs.gov/pub/irspdf/p557.pdf

Internal Revenue Service. (n.d.-a). Unrelated business income tax-General rules. Retrieved from http://web.archive.org/web/20050127092548/http://www.irs.gov/charities/ article/0, id=96104,00.html

Internal Revenue Service. (n.d.-b). Section 501(c)3 organizations. Retrieved from http://web. archive.org/web/20041118012537/http://www.irs.gov/publications/p557/ch03.html

Internal Revenue Service. (n.d.-c). Political and lobbying activities. Retrieved from http://web.archive.org/web/20050608095235/http://www.irs.gov/charities/charitable/ article/0,id=120703,00.html

Lemann, N. (1999). The big test: The secret history of the American meritocracy. New York: Farrar, Strauss and Giroux.

Restrictions on nonprofit activities for 501(c)(3) organizations. (n.d.). Retrieved from http://web. archive.org/web/20050207105910/http://www.alliance1.org/Public_Policy/IRS_rules.htm

Santayana, G. (1905). The life of reason, reason in common sense. New York: Scribner's.

Scrivner, G. N. (2001). A brief history of tax policy changes affecting charitable organizations. In J. S. Ott (Ed.), The nature of the nonprofit sector (pp. 126-142). Boulder: Westview.

Open Access This chapter is licensed under the terms of the Creative Commons AttributionNonCommercial 2.5 International License (http://creativecommons.org/licenses/by-nc/2.5/), which permits any noncommercial use, sharing, adaptation, distribution and reproduction in any medium or format, as long as you give appropriate credit to the original author(s) and the source, provide a link to the Creative Commons license and indicate if changes were made.

The images or other third party material in this chapter are included in the chapter's Creative Commons license, unless indicated otherwise in a credit line to the material. If material is not included in the chapter's Creative Commons license and your intended use is not permitted by statutory regulation or exceeds the permitted use, you will need to obtain permission directly from the copyright holder.

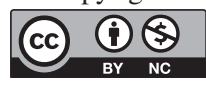

